\title{
ANALISIS PENGGUNAAN PUBLIC DEBT PADA PERUSAHAAN SEKTOR INDUSTRI MANUFAKTUR YANG TERDAFTAR DI BURSA EFEK INDONESIA
}

\author{
Riska Ayu Setiawati \\ Universitas Islam Negeri Sunan Ampel Surabaya \\ riska.ayu@uinsby.ac.id
}

\begin{abstract}
ABSTRAK
Penelitian ini bertujuan untuk meneliti menganalisis penggunaan public debt pada perusahaan sektor industri manufaktur yang terdaftar di Bursa Efek Indonesia, dengan menganalisa apa yang dipertimbangkan ketika perusahaan menggunakan public debt.. Karakteristik perusahaan yang digunakan dalam penelitian ini adalah umur perusahaan, ukuran perusahaan, tangible asset, financial leverage, earning volatility, growth opportunity dan public ownership. Teknik yang digunakan dalam penelitian ini adalah model analisis regresi Tobit karena data yang digunakan adalah data campuran. Sampel yang digunakan sebanyak 112 perusahaan yang berada di sektor industri manufaktur yang terdaftar di Bursa Efek Indonesia (BEI) selama lima tahun berturut turut. Hasil penelitian menunjukkan bahwa perusahaan yang menggunakan public debt, umur perusahaan berpengaruh negatif signifikan, ukuran perusahaan dan public ownership berpengaruh positif signifikan, sedangkan tangible asset dan growth opportunity berpengaruh negatif tidak signifikan, financial leverage dan earning volatility berpengaruh positif tidak signifikan.
\end{abstract}

Kata kunci: public debt, umur perusahaan, ukuran perusahaan, tangible asset, financial leverage,earning volatility, growth opportunity, public ownership.

\section{PENDAHULUAN}

Salah satu fungsi manajemen keuangan adalah fungsi pendanaan, dalam teori pendanaan pecking order theory, Myers and Majluf (1984) menemukan bahwa perusahaan akan cenderung lebih memilih pendanaan internal melalui laba ditahan, sebelum mencari dana keluar melalui utang dan saham. Pendanaan internal memiliki kekurangan yaitu terbatasnya dana yang dimiliki perusahaan sehingga utang menjadi pilihan pendanaan. Utang menurut sumber utang dibagi menjadi dua yaitu private debt dan public debt, private debt dalam hal ini adalah utang bank dan non bank, sedangkan public debt adalah penerbitan obligasi. Menurut Daydov (2009) perusahaan yang menggunakan private debt kinerjanya tidak lebih baik daripada perusahaan yang menggunakan public debt, hal ini dibuktikan dengan Tobin's q, dan berdasarkan return on equity perusahaan yang melakukan initial public offering debt, lebih tinggi daripada yang private debt.

Menurut data perusahaan manufaktur di Indonesia selama 2010-2014 lebih banyak 
Riska Ayu Setiawati

Analisis Penggunaan Public Debt Pada Perusahaan Sektor Industri Manufaktur yang

Terdaftar Di Bursa Efek Indonesia

Jurnal Manajemen dan Inovasi (MANOVA) Volume 3 Nomor 1, ISSN: 2685-4716

perusahaan yang menggunakan utang bank daripada obligasi, 55\% dari 112

perusahaan. Hal ini berarti di Indonesia perusahaan lebih banyak menggunakan utang bank sebagai pendanaan. Dari data yang dihimpun dan diolah menunjukkan bahwa secara nominal rupiah jumlah dana obligasi lebih besar daripada utang bank.

Gambar 1

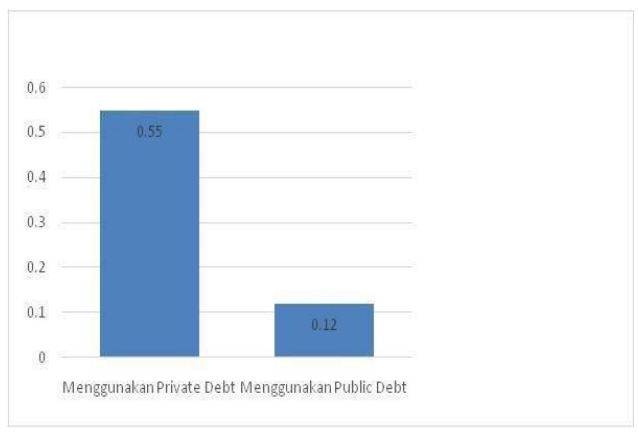

Tabel 1

\begin{tabular}{|c|c|}
\hline $\begin{array}{c}\text { Private Debt (Million } \\
\text { Rp) }\end{array}$ & $\begin{array}{c}\text { Public Debt (Million } \\
\text { Rp) }\end{array}$ \\
\hline $123,555,965$ & $172,415,793$ \\
\hline
\end{tabular}

Penelitian sebelumnya lebih banyak yang fokus pada pendanaan utang berdasarkan jangka waktunya, sedangkan berdasarkan sumber dana masih jarang dilakukan. Penelitian oleh Nor dan Puan (1999) Arikawa (2008) dan Yu (2003) berpengaruh negatif terhadap penggunaan sumber public debt, sedangkan dalam penelitan Nor dan Puan (1999) umur perusahaan, ukuran perusahaan, tangible asset, financial leverage, earning volatility, growth opportunity tidak berpengaruh terhadap penggunaan sumber public debt. Menurut Arikawa (2008) perusahaan akan menurunkan penggunaan utanga] bank dan beralih obligasi.

Berdasarkan fenomena yang telah diungkapkan, bahwa ada kecenderungan perusahaan lebih memilih sumber utang bank daripada obligasi tapi secara nominal banyak yang menggunakan public debt, sedangkan penelitian sebelumnya belum konsisten apa yang membuat perusahaan memilih sumber pendanaan public debt. Isu struktur utang lebih banyak diteliti dari segi jangka waktunya dan jarang yang meneliti dari sumber utang, sehingga penelitian ini akan meneliti apakah karakteristik perusahaan berupa umur perusahaan, ukuran perusahaan, earning volatility, tangible asset, financial leverage, peluang pertumbuhan perusahaan dan public ownership terhadap penggunaan public debt di perusahaan manufaktur di Indonesia. 


\section{TINJAUAN PUSTAKA}

\section{Pengertian Public Debt}

Utang adalah kewajiban perusahaan terhadap pihak luar karena terdapat dana yang bersumber dari dana eksternal, baik berasal dari perbankan, leasing penjualan obligasi dan sejenisnya Fahmi (2013:160). Sedangkan, public debt adalah surat utang yang dikeluarkan oleh perusahaan yang memerlukan dana (Huda dkk, 2008). Perusahaan yang menerbitkan public debt disebut debenture akan membayarkan kupon dan pokok pinjaman sesuai dengan isi surat utang, bedanya dengan utang private debt adalah adanya bank atau pihak ketiga yang memberikan utang dari dana yang dihimpun dari nasabah, sedangkan pada public debt yang memberikan utang adalah langsung pihak publik di pasar modal. Menurut Fama (1985) kreditur pada public debt, memiliki informasi yang terbatas yaitu yang tersedia di publik, misalnya hasil audit independen, laporan keuangan dan peringkat obligasi.

Public debt diukur dengan rasio total long term bond terhadap total long term debt, yang dirumuskan sebagai berikut:

$$
\text { Public debt }=\frac{\text { Total long termbond }}{\text { Totallong termdebt }}
$$

\section{Penggunaan Public Debt}

Penggunaan public debt sebagai pendanaan dalam penelitian Nor dan Puan (1999), Yu (2003), Arikawa (2008), Daydov (2009) dipengaruhi oleh beberapa variabel internal perusahaan diantaranya, umur perusahaan, ukuran perusahaan, aset tetap, financial leverage, growth opportunities, earning volatility, , public ownership.

\section{Umur perusahaan}

Menurut Yu (2003) umur perusahaan adalah seberapa lama perusahaan sejak pertama kali didirikan. Menurut Ulum (2009) umur perusahaan adalah bagian dari dokumentasi yang menunjukkan tentang apa yang tengah dan yang akan diraih oleh perusahaan. Menurut Diamond (1991), umur perusahaan dianggap sebagai proksi dari reputasi perusahaan, semakin lama perusahaan berdiri menunjukkan keberhasilan perusahaan dalam bertahan dalam persaingan. Semakin lama perusahaan berdiri masalah asymmetric information lebih kecil, dibandingkan perusahaan yang baru berdiri. Umur perusahaan diukur dengan menggunakan logaritma natural dari umur perusahaan sampai penelitian dilakukan

Dalam teori teori asymetric information pihak manajemen memiliki informasi yang lengkap terkait kondisi perusahaan, sedangkan pihak 
Riska Ayu Setiawati

Analisis Penggunaan Public Debt Pada Perusahaan Sektor Industri Manufaktur yang

Terdaftar Di Bursa Efek Indonesia

Jurnal Manajemen dan Inovasi (MANOVA) Volume 3 Nomor 1, ISSN: 2685-4716

pemegang saham tidak, sehingga hal ini beresiko menyebabkan moral

hazard, salah satunya adalah pengambilan keputusan manajer yang menguntungkan sebelah pihak, hal ini melanggar kontrak dan secara etika atau norma mungkin tidak layak dilakukan. Dalam teori yang dikemukakan Diamond (1984), utang menjadi salah satu mitigasi dari potensi moral hazard, karena adanya pengawasan yang dilakukan oleh kreditur.

Perusahaan yang sudah berdiri lama memiliki kualitas yang baik akan lebih memilih pendanaan dengan public debt (Diamond, 1991 dan Rajan 1992), hal ini dapat mengatasi masalah monopoli informasi oleh bank dan mengurangi offsetting cost. Dalam penelitian Yu (2003) umur perusahaan berpengaruh negatif signifikan terhadap public debt, sedangkan menurut Nor \& Puan (1999) umur perusahaan berpengaruh negatif tidak signifikan terhadap public debt.

\section{Ukuran perusahaan}

Menurut Riyanto (2008 : 313), besar kecilnya perusahaan dilihat dari besarnya nilai equity, nilai penjualan atau nilai aktiva. Dalam teori trade off struktur modal menyebutkan bahwa semakin besar ukuran perusahaan maka akan lebih mudah memperoleh utang dan lebih besar kapasitas utang yang bisa diperoleh (Marsh, 1982 dan Rajan \& Zingales (1995)).Pada ukuran perusahaan tertentu perusahaan akan beralih dari private debt ke public debt, karena menurut Blackwell dan Kidwell (1998) penggunaan utang publik memerlukan biaya emisi substansial, termasuk komponen fixed cost yang besar. Perusahaan hanya akan memasuki pasar modal dengan menerbitkan obligasi ketika membutuhkan jumlah utang yang besar untuk mendapatkan keuntungan dari skala ekonomi, sehingga perusahaan yang berukuran besar akan menggunakan public debt (Denis dan Mihov, 2003), sehingga ukuran perusahaan berpengaruh positif terhadap penggunaan public debt.

Ukuran perusahaan diukur menggunakan total aset, karena total aset perusahaan bernilai besar maka hal ini dapat disederhanakan dengan mentransformasikan kedalam logaritma natural (Ghozali, 2006). Dalam penelitian Yu (2003), Denis \& Mihov (2002) dan Arikawa (2008) ukuran perusahaan berpengaruh positif signifikan terhadap penggunaan public debt, sedangkan menurut Noor \& Puan (1999) umur perusahaan berpengaruh positif tapi tidak signifikan terhadap penggunaan public debt.

\section{Aset tetap (tangible asset)}

Menurut Murhadi (2013: 21) aset tetap (tangible asset) adalah kekayaan perusahaan yang dimiliki perusahaan dan memberikan manfaat lebih dari 
satu periode. Aset tetap meliputi tanah, pabrik, gedung, peralatan dan mesin, aset tetap digunakan sebagai proksi dari nilai jaminan. Perusahaan dengan asset tetap yang besar, memiliki nilai jaminan yang lebih besar, sehingga akan lebih mudah memperoleh utang dan membuat peringkat obligasinya jadi baik. Perusahaan yang memiliki aset tetap yang rendah akan cenderung menggunakan public debt, karena private debt lebih khususnya utang lebih banyak menuntut untuk jaminan.

Dalam penelitian Denis dan Mihov (2003), menyatakan bahwa perusahaan dengan kualitas kredit yang tinggi akan meminjam dari sumber public, sedangkan perusahaan dengan kualitas kredit yang medium akan meminjam dari bank dan yang memiliki kualitas kredit yang rendah cenderung akan meminjam ke private non bank, artinya perusahaan yang memiliki kualitas kredit yang baik tidak perlu aset tetap sebagai jaminan akan utangnya.Dalam penelitian Yu (2003) dan Arikawa (2008) tangible asset berpengaruh negatif signifikan terhadap penggunaan public debt, sedangkan menurut Noor \& Puan (1999) tangible asset berpengaruh positif tidak signifikan terhadap penggunaan public debt dan menurut Denis \& Mihov (2002) tangible asset berpengaruh negatif signifikan terhadap penggunaan public debt.

\section{Financial leverage}

Financial leverage timbul karena perusahaan dibelanjai dengan dana yang menimbulkan beban tetap, yaitu berupa utang, dengan beban tetapnya berupa bunga. Financial leverage (Sudana, 2011: 157). Perusahaan dengan financial leverage yang tinggi akan memilih utang bank karena pihak bank bisa melakukan fungsi monitoring dan screening terhadap utang perusahaan. Dalam penelitian Denis dan Mihov (2002) menyatakan perusahaan dengan financial leverage yang tinggi memilih pendanaan private debt karena pihak bank lebih tahu detail informasi tentang perusahaan, sehingga akan lebih mudah untuk renegosiasi jika perusahaan mengalami financial distress hingga kebangkrutan. Bank juga lebih ingin membangun hubungan jangka panjang dengan perusahaan, sedangkan kreditur public debt lebih tidak tertarik dengan prespektif masa depan dari perusahaan, sehingga akan lebih menuntut likuidasi jika terjadi kebangkrutan (Chemmanur \& Fulghieri, 1994).

Dalam penelitin Yu (2003) Arikawa (2008) financial leverage berpengaruh negatif signifikan terhadap penggunaan public debt, sedangkan dalam Denis \& Mihov (2002) financial leverage berpengaruh positif signifikan dan Noor \& Puan (1999) financial leverage berpengaruh positif tidak signifikan terhadap penggunaan public debt.

\section{Earnings volatility}

Earning volatilitility adalah fluktuasi pendapatan yang diperoleh perusahaan 
selama periode tertentu. Semakin fluktuatif pendapatan perusahaan semakin sulit untuk melunasi kewjjiban perusahaan. Earning volatility mencerminkan besar kecilnya risiko dan kemungkinan financial distress perusahaan Johnson (1997), earning volatility menggambarkan risiko kredit, maka utang bank jangka panjang akan berkurang dengan meningkatnya earning volatility. Perusahaan yang tidak memperoleh utang bank karena risiko kredit yang tinggi akan lebih memilih public debt sebagai pendanaan, tapi perusahaan dengan risiko kredit yang tinggi harus membayar kupon yang tinggi sebagai imbalan risiko yang dihadapi kreditur public debt. Earning volatilitility diukur dengan menghitung standar deviasi dari earning before interst and tax (ebit).

Menurut Arikawa (2008) earning volatility berpengaruh negatif signifikan terhadap penggunaan public debt, sedangkan menurut Noor \& Puan (1999) dan $\mathrm{Yu}$ (2003) earning volatility berpengaruh negatif tidak signifikan terhadap penggunaan public debt.

\section{Peluang pertumbuhan (growth opportunities)}

Menurut Chung dan Charoenwong (1991) peluang pertumbuhan perusahaan adalah kesempatan investasi yang menghasilkan keuntungan . Jika kesempatan investasi memberi keuntungan besar, maka manajer akan mengambil peluang tersebut untuk memaksimalkan kesejahteraan pemegang saham dengan melakukan investasi. Semakin besar peluang invesatasi maka akan memerlukan dana yang lebih besar, sehingga perusahaan akan mempertimbangkan untuk berutang.

Perusahaan dengan growth opportunity yang tinggi identik dengan perusahaan dengan kualitas yang bagus dan kinerja yang baik. Menurut Arikawa (2008) semakin besar growth opportunity, maka perusahaan akan mengurangi ketergantungan dengan bank untuk menghindari hold up problem (masalah komitmen) karena pihak bank akan banyak ikut campur dalam keputusan perusahaan. Menurut Hoshi, Kashyap, dan Scharfstein (1991) perusahaan yang memiliki kinerja yang baik yang ditunjukkan dengan tingkat pertumbuhan yang tinggi akan lebih memilih public debt karena memiliki agency problem dan level monitoring yang lebih rendah, berarti semakin tinggi peluang pertumbuhan maka perusahaan akan mengurangi private debt dan lebih memilh public debt.

Dalam penelitian Arikawa (2008) peluang pertumbuhan berpengaruh positif signifikan terhadap penggunaan public debt, sedangkan menurut Noor \& Puan (1999) peluang pertumbuhan berpengaruh positif tidak signifikan terhadap penggunaan public debt, Yu (2003) menemukan bahwa peluang pertumbuhan berpengaruh negatif signifikan terhadap penggunaan public debt, demikian juga penelitian Denis \& Mihov (2002) growth opportunity 
Riska Ayu Setiawati

Analisis Penggunaan Public Debt Pada Perusahaan Sektor Industri Manufaktur yang

Terdaftar Di Bursa Efek Indonesia

Jurnal Manajemen dan Inovasi (MANOVA) Volume 3 Nomor 1, ISSN : 2685-4716

berpengaruh negatif tidak signifikan terhadap penggunaan public debt.

\section{Public ownership}

Kepemilikan publik adalah proporsi kepemilikan saham perusahaan oleh masyarakat umum atau oleh pihak luar. Dalam hal ini yang dimaksud pihak luar adalah masyarakat umum yang bukan bagian dan pihak perusahaan. Public ownership diukur dengan membandingkan jumlah lembar saham yang dimiliki oleh publik terhadap jumlah lembar saham secara keseluruhan.

Komposisi pemegang saham yang besar akan meningkatkan terpilihnya anggota dewan direksi dan dewan komisaris yang berasal dari luar, hal ini akan memengaruhi kinerja perusahaan. Anggota dewan direksi dan komisaris yang berasal dari luar akan lebih mengutamakan kesejahteraan pemegang saham publik, sehingga akan keputusan yang dibuat akan dapat memaksimalkan kesejahteraan pemegang saham publik. Kepemilikan saham publik akan lebih menginginkan adanya pihak ketiga, seperti bank untuk melakukan monitoring terhadap setiap keputusan manajer Meginson (1997), karena menurutnya adanya lembaga keuangan akan banyak melakukan monitoring dan dapat mengurangi asimetrik informasi dan masalah agensi. Public ownership akan berpengaruh positif terhadap penggunaan public debt, karena private debt yang berasal dari bank memiliki keterbatasan dana, pemegang saham publik lebih menginginkan perusahaan menerbitkan public debt untuk memperoleh tambahan dana melalui public debt daripada mengeluarkan saham, karena mengeluarkan saham akan mengurangi proporsi kepemilikan pemegang saham publik yang ada.

\section{Rerangka Penelitian}

Gambar 2 Rerangka Penelitian

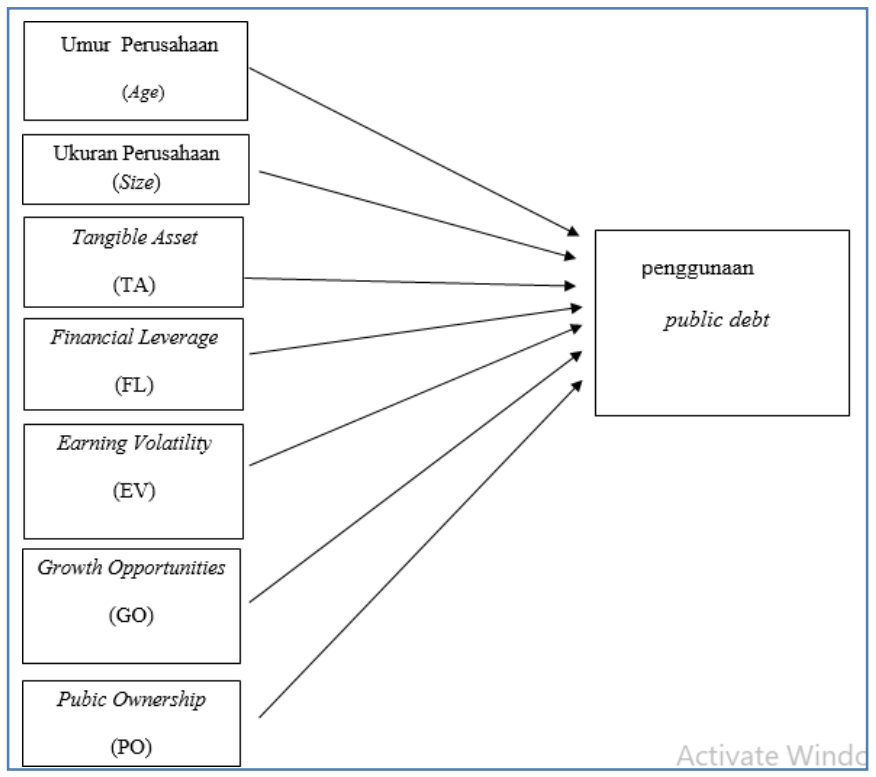




\section{Model Penelitian}

Public debt model $=\beta 0+\beta 1.2$ Ageit $+\beta 2.2$ Size it $+\beta 3.2 \mathrm{TA}$ it $+\beta 4.2 \mathrm{FL}$ it

$$
+\beta 5.2 \mathrm{EV} \text { it }+\beta 6.2 \mathrm{GO} \text { it }+\beta 7.2 \mathrm{PO} \text { it }+\varepsilon \mathrm{t}
$$

\section{Metode Penelitian}

\section{Definisi Operasional}

Tabel 2 Definisi Operasional Variabel Penelitian

\begin{tabular}{|c|c|}
\hline \multicolumn{2}{|l|}{ Variabel Dependen } \\
\hline \multirow{2}{*}{ Private Debt } & Total long term bank debt \\
\hline & Totallong termdebt \\
\hline \multirow[t]{2}{*}{ Public Debt } & Total long term bond \\
\hline & Totallong term debt \\
\hline \multicolumn{2}{|l|}{ Variabel Independen } \\
\hline Umur Perusahaan (Age) & Ln (age firm, in yearsfrom date ofincorporation) \\
\hline Ukuran Perusahaan (Size) & Ln (Total Asset) \\
\hline \multirow{2}{*}{ Tangible Asset (TA) } & Fixed asset \\
\hline & $\begin{array}{l}\text { Total Asset } \\
\text { TotalUtang Penelitian }\end{array}$ \\
\hline Financial Leverage (FL) & Total Asset $\quad$ Sampel \\
\hline \multirow[t]{3}{*}{ Earning Volatility (EV) } & digunakan \\
\hline & $\sum_{i=1}^{N}(E B I T i-\overline{E B I T})^{2}$ \\
\hline & yang tercatat dan \\
\hline \multirow[t]{2}{*}{ Growth Opportunity (GO) } & Total histed share $t$ X stock closing price \\
\hline & Total equity $_{\mathrm{t}}$ \\
\hline \multirow{2}{*}{$\begin{array}{l}\text { Public Ownership (PO) } \\
\text { menerbitkan }\end{array}$} & The number of shares owned by the public \\
\hline & Total number of shares \\
\hline
\end{tabular}

Bursa Efek Indonesia (BEI) dengan jumlah sampel yang dapat digunakan dalam penelitian ini adalah 112 perusahaan dengan periode pengamatan lima tahun, sehingga dalam penelitian ini terdapat 560 observasi.

\section{Prosedur Pengumpulan Data}

Teknik pengumpulan data yang digunakan adalah teknik dokumentasi, yaitu dengan mengumpulkan data sekunder dari laporan keuangan perusahaan (laporan laba rugi, neraca, dan catatan laporan keuangan).

\section{Teknik Analisis}

Teknik analisis data yang digunakan untuk menguji hipotesis adalah model 
analisis regresi Tobit, analisis ini digunakan karena data dalam penelitian ini adalah data campuran, yaitu variabel terikat memiliki nilai nol untuk sebagian pengamatan, sedangkan untuk pengamavtan yang lain memiliki nilai yang bervariasi, sehingga data tersebut termasuk data tersensor (censored data).

\section{Hasil dan Pembahasan}

Tabel 3 Hasil Regresi Tobit Struktur Utang dan Karakteristik Perusahaan

\begin{tabular}{|l|l|l|}
\multirow{2}{*}{$\begin{array}{c}\text { Variabel } \\
\text { Dependen }\end{array}$} & \multicolumn{2}{c|}{ Public Debt } \\
\cline { 2 - 3 } & Koefisien & Signifikansi \\
\hline Intercept & -4.715296 & 0.0000 \\
\hline Age & -0.547444 & $0.0041^{*}$ \\
\hline Size & 0.368504 & $0.0000^{*}$ \\
\hline TA & -0.457329 & 0.1458 \\
\hline FL & 0.242914 & 0.1436 \\
\hline EV & 4.527168 & 0.1525 \\
\hline GO & -0.009011 & 0.5298 \\
\hline PO & 1.055971 & $0.0057^{*}$ \\
\hline
\end{tabular}

Keterangan: ${ }^{*}$ signifikan pada $1 \%,{ }^{* *}$ signifikan pada $5 \%,{ }^{* * *}$ signifikan pada $10 \%$

1. Umur perusahaan (Age) berpengaruh negatif signifikan terhadap proporsi penggunaan public debt, yang artinya semakin lama perusahaan berdiri maka proporsi penggunaan public debt berkurang hal ini menurut $\mathrm{Yu}$ (2003) karena semakin lama perusahaan berdiri, maka perusahaan cenderung lebih memilih pendanaan jangka panjang melalui pasar saham daripada pasar obligasi untuk memenuhi pendanaannya. Hasil penelitian ini konsisten dengan penelitian $\mathrm{Yu}$ (2003), yang menyatakan bahwa umur perusahaan berpengaruh negatif signifikan terhadap proporsi penggunaan private debt, sedangkan penelitian Nor \& Puan (1999) berpengaruh negatif tapi tidak signifikan.

2. Ukuran perusahaan (Size) berpengaruh positif signifikan terhadap proporsi penggunaan public debt, yang artinya semakin besar perusahaan maka semakin besar penggunaan public debt, dengan semakin besarnya ukuran perusahaan akan memudahkan perusahaan mengakses ke pasar modal (public debt) yang membutuhkan biaya emisi substansial dan komponen fixed cost yang besar tapi menjanjikan jumlah nominal yang besar jugax.

3. Tangible asset (TA) berpengaruh negatif tidak signifikan terhadap proporsi penggunaan public debt, pengaruh negatif tangible asset karena tangible asset 
lebih banyak digunakan sebagai jaminan untuk private debt, sehingga ketika perusahaan memiliki tangible asset yang besar perusahaan akan lebih memilih menambah porsi private debt daripada public debt. Tangible asset berpengaruh tidak signifikan, sehingga tangible asset tidak menjadi faktor penentu dalam proporsi penggunaan public debt, karena tangible asset lebih dipertimbangkan ketika perusahaan akan berutang di bank, pihak bank menggunakan tangible asset sebagai jaminan, sedangkan obligasi relatif jarang menggunakan jaminan.

4. Financial leverage (FL) berpengaruh positif tidak signifikan terhadap proporsi penggunaan public debt, yang artinya semakin besar financial leverage juga akan meningkatkan penggunaan public debt, hal ini karena perusahaan dengan financial leverage yang tinggi memiliki risiko gagal bayar yang tinggi karena perusahaan mempunyai private debt yang terlalu banyak, sehingga pihak bank akan mempersulit pemberian utang, sehingga pendanaan public debt menjadi alternatif yang relatif lebih mudah. Financial leverage berpengaruh tidak signifikan, berarti tidak menjadi faktor penentu dalam proporsi penggunaan public debt. Hal ini karena perusahaan yang memperoleh utang yang cukup dari bank tidak mempertimbangkan public debt.

5. Earning volatility $(\boldsymbol{E} \boldsymbol{V})$ berpengaruh positif tidak signifikan terhadap proporsi penggunaan public debt, pengaruh positif artinya semakin fluktuatuif maka perusahaan justru cenderung menggunakan public debt, karena perusahaan yang tidak memperoleh utang bank karena risiko kredit yang tinggi akan menggunakan public debt sebagai pendanaan, tapi perusahaan dengan risiko kredit yang tinggi harus membayar kupon yang tinggi sebagai imbalan risiko yang dihadapi kreditur public debt. Earning volatility berpengaruh tidak signifikan, berarti tidak menjadi faktor penentu dalam proporsi penggunaan public debt.

6. Growth opportunity $(\boldsymbol{G O})$ berpengaruh negatif tidak signifikan terhadap proporsi penggunaan public debt, pengaruh negatif growth opportunities menurut Yu (2003) karena perusahaan dengan growth opportunities yang tinggi membutuhkan dana yang besar untuk melakukan investasi, sehingga perusahaan lebih memilih untuk menerbitkan saham.

7. Public Ownership (PO) berpengaruh positif signifikan terhadap penggunaan public debt, yang artinya semakin besar kepemilikan publik maka perusahaan lebih menginginkan menggunakan public debt dalam pendanaannya. Hal ini karena utang bank memiliki batas, sehingga untuk menambah pendanaan pemegang saham publik akan menggunakan public debt, pemegang saham publik lebih mempertibangkan public debt, daripada mengeluarkan saham baru, karena menerbitkan saham baru akan mengurangi proporsi kepemilikan investor.

\section{Simpulan dan Saran Simpulan}


Berdasarkan hasil penelitian yang telah dilakukan, maka dapat diambil kesimpulan sebagai berikut:

1. Umur perusahaan berpengaruh negatif signifikan, sedangkan ukuran perusahaan dan public ownership berpengaruh positif signifikan terhadap proporsi penggunaan public debt. Tangible asset dan growth opportunity berpengaruh negatif tidak signifikan, sedangkan financial leverage dan earning volatility berpengaruh positif tidak signifikan terhadap proporsi penggunaan public debt.

2. Dalam menentukan proporsi penggunaan public debt yang dipertimbangkan adalah umur perusahaan, ukuran perusahaan dan public ownership.

\section{Saran}

Berdasarkan pembahasan yang telah dilakukan, saran yang diberika adalah sebagai berikut:

1. Bagi kalangan akademik, penelitian tentang determinan debt structure berdasarkan sumber utang di Indonesia masih sedikit, maka diharapkan selanjutnya akan banyak yang meneliti dengan topik serupa, sehingga bisa dijadikan refrensi.

2. Bagi manajer perusahaan, jika akan menggunakan public debt, harus mempertimbangkan umur perusahaan, ukuran perusahaan dan public ownership.

3. Bagi investor, dapat menganalisis proporsi penggunaan public debt yang digunakan perusahaan yaitu dengan mempertimbangkan umur perusahaan, ukuran perusahaan, tangible asset, financial leverage, earning volatility, growth opportunity dan public ownership untuk private debt, sedangkan untuk public debt, investor dapat mempertimbangkan umur perusahaan, ukuran perusahaan dan public ownership

4. Bagi para peneliti berikutnya, yang akan melakukan penelitian selanjutnya dengan topik serupa, dapat menambahkan faktor eksternal perusahaan, karena penelitian ini hanya fokus pada faktor internal perusahaan dan juga dapat menambahkan periode penelitian. 


\section{DAFTAR PUSTAKA}

Arikawa, Y. (2008). The choice between public and private debt by Japanese firms. Journal of International Economic Studies 22:1, 19 $-30$

Blackwell D.W., Kidwell D.S. (1998). An investigation of cost differences between public sales and private placements of debt. Journal of Financial Economics, 22: 253-278.

Chemmanur, T.J dan Fulghieri, P.(1994). Investment Bank Reputation, Information Production, And Financial Intermediation. Journal of Finance, 49 (1): 57-79.

Chung, Kee. H, and Charoenwong, Charlie. (1991). "Investment Options, Assets in Place, and the Risk of Stocks". Financial Management Vol. 20, No. 3 (Autumn, 1991), pp. 21-33. UK \& USA. Blackwell Publishers Ltd.

Denis, Davydov (2009). Does The Choice Between Bank Loans And Bonds Affect Firm Performance? Evidence from the Russian Federation. Thesis. Finland : Accounting and Finance. University Of Vaasa.

Denis, D. J. and V. T. Mihov (2002). The choice among bank debt, non bank private debt, and public debt: evidence from new corporate borrowings. Journal of Financial Economics 70:1, 3 - 28.

Diamond, D. (1984). Financial intermediation and delegated monitoring. Review of Financial Studies, 59, pp. 393-414.

Diamond, D. (1991). Monitoring and reputation: the choice between bank loans and directly placed debt. Journal of Political Economy 99, pp. 689-721.

Fama, E.F. (1985). What's different about banks. Journal of Monetary Economics 15, pp. 29-39.

Ghozali, Imam. (2006). Aplikasi Analisis Multivariate Dengan Program SPSS. Cetakan Keempat. Semarang: Badan Penerbit Universitas Diponegoro.

Hoshi,T., Kashyap, A., and D. Scharfstein (1993) "The choice between public and private debt: an analysis of post deregulation corporate financing in Japan, ” NBER Working Paper 4421.

Huda. Nurul dan Mustafa Edwin Nasution. (2008). Investasi pada Pasar Modal Syariah. Jakarta : Kencana. 
Johnson, S.A. (1997). An empirical analysis of the determinants of corporate debt ownership structure. Journal of Financial and Quantitative Analysis, 32 (1): 47-69.

Marsh, P. (1982), "The choice between equity and debt: an empirical study", The Journal of Finance, Vol. 37, pp. 121-44. Megginson,W.L. (1997). Corporate Finance Theory. Addison-Wesley Educational Publishers Inc.

Murhadi, Werner R. 2013. Analisis Laporan Keuangan Proyeksi dan Valuasi Saham. Jakarta: Salemba Empat

Myers, S.C., 1977, "The Determinant of Corporate Borowing," Journal of Financial Economics 5: 147-176.

Nor, F.M and Puan,C.Y (1999). Determinants Of Corporate Debt Ownership Structure in Malaysia. Thesis. Malaysia : Finance. Universiti Kebangsaan Malaysia.

Rajan, R. (1992). Insiders And Outsiders: The Choice Between Informed And Arm 's-Length Debt. Journal of Finance 47, pp. 1367-1400.

Rajan, R.G. dan Zingales, I. 1995. What do we know about capital structure? Some evidence from international data, Journal of Finance, Vol. 50: 1421-1460.

Riyanto, Bambang. (1995). Dasar-dasar pembelanjaan perusahaan. Edisi keempat. Yogyakarta: Yayasan Penerbit Gajah Mada.

Sudana, I Made. 2011. Manajemen Keuangan Perusahaan (Teori dan Praktek). Surabaya: Erlangga.

Ulum, Ihyaul, 2009. Intellectual Capital: Konsep dan Kajian Empiris, Graha Ilmu, Yogyakarta

Yu, Hai-Chin (2003). Public Debt, Bank Debt and Non-bank Private Debt and Firm Characteristics Among Taiwanese Listed Companies. FMA 2003 Annual Meeting.

Yu, H.C., Johnson, K.H., and Tzon.D., 2008, "Public debt, bank debt, and non-bank private debt in emerging and developed financial markets." Bank and Bank Systems, Vol 81 : 607-636.

$\underline{\text { www.idx.co.id }}$ 